\title{
Laboratory Evaluation of Ethanol Production from Jatropha Curcas as Compared to A Selected Sugarcane Variety (DB 7869)
}

\author{
Zareefa Bacchus and Gomathinayagam Subramanian* \\ Faculty of Agriculture and Forestry, University of Guyana Berbice Campus, Tain, Berbice, Guyana, South America
}

*Corresponding author: Gomathinayagam Subramanian, Faculty of Agriculture and Forestry, University of Guyana

Berbice Campus, Tain, Berbice, Guyana, South America

\section{ARTICLE INFO}

Received: 㗀 July 16, 2021

Published: 幽 August 05, 2021

Citation: Zareefa Bacchus, Gomathinayagam Subramanian. Laboratory Evaluation of Ethanol Production from Jatropha Curcas as Compared to A Selected Sugarcane Variety (DB 7869). Biomed J Sci \& Tech Res 37(5)-2021. BJSTR. MS.ID.006062.

Keywords: Jatropha Curcas; Ethanol DB 7869; Biofuel; Sugarcane; Saccharomyces Cereviseae

\begin{abstract}
This is driving research to use Ethanol as a transportation fuel in view of the fact that it is more efficient, cleaner and a cheaper source of energy. Engines have been converted for the use of ethanol in countries like Brazil, India, United States of America. Jatropha curcas or commonly called 'physic nut' is of the Euphorbiaceae family, a perennial crop, with a higher efficiency of biofuel production than Sugarcane, a crop that requires limited attention in its cultivation. Jatropha curcas is seen as having potentials for commercial production in Guyana, as such large-scale cultivation will commence in the near future so as to reduce fuel importation cost, create a cleaner atmosphere and aid in creating job opportunities. Sugarcane occupies some 50,000 ha of land along the coast of Guyana. The potential for commercial ethanol production from sugarcane has been extensively studied in recent years by Guyana Sugar Cooperation (Guysuco) and other agencies with the interest to increase the diversity of products from sugarcane. The procedure for this project involves primarily laboratory work in which Jatropha curcas leaves and seeds were collected as well as Sugarcane variety (DB 7869) juice, isolated with yeast, Saccharomyces cereviseae and fermented for a week. Ethanol produced from these materials was obtained from simple distillation. The results attain showed that Jatropha curcas produced a higher percentage of ethanol than Sugarcane variety (DB 7869). The quality (percentage of alcohol) and purity (alcohols/esters) of the ethanol was tested at Demerara Distillers Limited (DDL) and Guyana Pharmaceuticals Company (GPC), in which Sugarcane variety DB 7869 was found to be purer than Jatropha curcas. This experiment was done on a small scale and a lot of knowledge was acquired about the ability of producing biofuel from both of these plants however, further research needs to be carried out on a larger scale to enhance the results and to pick up what has been overlooked, all for the benefit of commercial production and a cleaner atmosphere.
\end{abstract}

\section{Introduction}

The world has been traditionally dependent on fossil fuels for industrial and other productive activities. However, the use of these types of fuels over the years has contributed to global warming, depletion of the ozone layer and the ultimate effect - climatic changes. To reduce global warming and other effects, there has been a concerted effort to produce a fuel that has minimum exhaust emissions. In the quest for an alternative energy source, organic materials are being exploited daily in search of a more efficient, cleaner and cheaper energy source (fuel). Ethanol mixed with $10 \%$ gasoline requires no modification for modern day vehicle. Although ethanol is used in the pharmaceutical industries, the main focus today is on fuel production. Ethanol is produced mainly by fermentation of fruits, vegetables, cellulosic plant materials, and plant/animal wastes. Jatropha, a perennial crop that has a higher efficiency of biofuel production than sugar cane as it gives 19,800-26,400 Energetic equivalent kwh/ha as opposed to 16,000 (Saccharum 
officinarum). Belonging to the family Euphorbiaceae, Jatropha is a plant that does not need much attention in its cultivation; it adapts to a wide range of climates and soils, produces seeds even after decades of planting, replenishes the soil it grows on and requires little or no fertilization. Sugarcane accounts for some 50,000 ha of land along the coast of Guyana. Yearly production rate ranges from 320,000 to 350,000 tonnes from 5 estates. Domestic consumption uses about 35,000 tonnes. The potential for commercial ethanol production from sugarcane has been extensively studied in recent years.

Fermentation is strongly influenced by temperature because the yeast performs best in a specific temperature range. The rate of fermentation increases with temperature in temperature range between $80^{\circ} \mathrm{F}\left(27^{\circ} \mathrm{C}\right)$ and $950 \mathrm{~F}\left(35^{\circ} \mathrm{C}\right)$. Above $95 \mathrm{oF}\left(35^{\circ} \mathrm{C}\right)$, the rate of fermentation gradually drops off and ceases altogether at temperature above $109^{\circ} \mathrm{F}\left(43^{\circ} \mathrm{C}\right)$. The actual temperature effects vary with different yeast strains and typical operating conditions are closer to $80 \mathrm{oF}\left(27^{\circ} \mathrm{C}\right)$ than $95 \mathrm{oF}\left(35^{\circ} \mathrm{C}\right)$. this choice is usually made to reduce ethanol loss by evaporation. For every $9 \mathrm{oF}\left(5^{\circ} \mathrm{C}\right)$ increase in temperature, the ethanol evaporation rate increases 1.5 times (Nathan, 1978). Saccharomyces cereviseae are most effective in $\mathrm{pH}$ ranges between 3.0 and 5.0. The cause of premature flocculation seems to be a function of the $\mathrm{pH}$ of the mash and the number of free calcium ions in the solution. Hydrated lime is sometimes added to adjust the $\mathrm{pH}$. Sugar concentration There are two basic concerns that govern the sugar concentration of the substrate: [1] excessively high sugar concentrations can inhibit the growth of yeast cells in the initial stages of fermentation and [2] high ethanol concentrations are lethal to yeast. If the concentration of ethanol in the solution reaches levels high enough to kill yeast before all the sugar is consumed, the quantity of sugar that remains is wasted. Yeast growth problems can be overcome by using large inoculations to start fermentation. Saccharomyces strains can utilize effectively all of the sugar in solutions that are $16 \%$ to $22 \%$ sugar while producing beer that ranges from $8 \%$ to $12 \%$ ethanol by volume.

Yeast strains are divided informally into top and bottom yeast according to the location in the mash in which most of the fermentation takes place. The top yeasts Saccharomyces cereviseae, produce carbon dioxide and ethanol vigorously and tend to cluster on the surface of the substrate. Producers of distilled spirits use top yeasts of high activity to maximize ethanol yield in the shortest time (Campbell I. and Duffus J.H, Yeast, 1988).

Nutritional Requirement Yeasts are plants, despite the fact that they contain no chlorophyll. As such, their nutritional requirements must be met, or they cannot produce ethanol as fast as desired. An energy source such as carbohydrates must be provided for metabolism. Amino acids must be provided in the proper proportion and major chemical elements such as carbon, nitrogen, phosphorus and others must be available to promote cell growth [3]. According to Ochse (1980), "the young leaves may be safely eaten, steamed or stewed." They are favored for cooking with goat meat, said to counteract the peculiar smell. Though purgative, the nuts are sometimes roasted and dangerously eaten. In India, pounded leaves are applied near horses' eyes to repel flies. The oil has been used for illumination, soap, candles, adulteration of olive oil, and making Turkey red oil. Alternate uses of the oil include climatic protection, varnishes, organic insecticide, and medicine for skin diseases, cancer, piles, snakebite, paralysis, dropsy and many more. Nuts can be strung on grass and burned like candlenuts [4]. Mexicans grow the shrub as a host for the lac insect. Ashes of the burned root are used as a salt substitute $[5,6]$ conclude that it has strong molluscicidal activity. Duke and Wain (1981) list it for homicide, pesticide, and raticide as well. The latex was strongly inhibitory to watermelon mosaic virus [7]. Bark used as a fish poison [8]. In South Sudan, the seed as well as the fruit is used as a contraceptive (List and Horhammer, 1969-1979). Sap stains linen and can be used for marking [9]. Little, Woodbury, and Wadsworth (1974) list the species as a honey plant.

\section{Martial and Methods}

\section{Selection of the Best Media for Yeast Growth}

$500 \mathrm{ml}$ of different culture medium was prepared as such as Potato Dextrose Agar (PDA), Potato Dextrose Yeast Extract Agar (PDYEA), Oatmeal Agar (OMA) and Universal Yeast Medium (YM.).

\section{Effect of Various pH $(4,5,6,7,8,9)$ on the Growth of Yeast Culture}

In this experiment broth was prepared based on the media the yeast grows best on. As observed both PDYEA and the Universal Yeast Medium showed the best growth in terms of colony count. However, as noted the PDYEA gave large colonies. And as such the broth of PDYEA was prepared.

\section{Effect of Various Temperatures (20oC, 25oC, 30oC, 35oC, 40oC) on the Growth of Yeast}

The Potatoes Dextrose Yeast Extract Broth (PDYEB) prepared by standard protocol and then poured in five (5) $125 \mathrm{ml}$ conical flasks, flasks were cotton plugged and autoclaved for 20 psi. Three (3) grams of yeast was added into each flask. The flasks were placed in water baths and regulated at temperatures $\left(20^{\circ} \mathrm{C}, 25^{\circ} \mathrm{C}, 30^{\circ} \mathrm{C}\right.$, $35^{\circ} \mathrm{C}, 40^{\circ} \mathrm{C}$ ) and maintained during this experiment. The broth was then filtered using Watman's filter paper at the two days interval after observation to determine the mass growth of the culture. The initial weight and the wet weight of the filter paper were recorded. The filter paper was oven dried at $100{ }^{\circ} \mathrm{C}$ for one (1) hour and the dry weight was also recorded. 


\section{Results and Discussion}

The number of colonies seen from culturing on PDYEA was much more in quantity and size as compared to all the other media used in this experiment. PDA followed next with a consistent increase in colonies from week 1 to 4 ; then a drastic increase in week 5 and continued with a steady increase until week 7. Figures 1-4. However, PDA produced smaller colony size. UYM was third in line to produce the largest quantity of colonies with a steady increase up to week 3 followed by a sharp increase unto week 6 then a gradual increase into week 7. The colony size obtained from UYM was smaller than PDYEA but larger than PDA. OMA on the other hand produced the least number of colonies with the smallest size $[10,11]$. As shown in Table $1 \mathrm{pH}$ has a great influence on the growth of mycelium (Sacchromyces cerevisiae). $\mathrm{pH} 7$ has dominated throughout the growth period (seven days). $\mathrm{pH} 6$ on the other hand did fairly well with the lowest results obtained from $\mathrm{pH}$ 4 and 8. Yeast (Sacchromyces cerevisiae) grows best on pH ranging from 5-6, but conditions in Guyana are different, as such the $\mathrm{pH}$ that was most outstanding throughout the testing period was 7 and as such this was selected to culture the yeast. At temperature $30^{\circ} \mathrm{C}$, from day 1 to day 7 the growth of mycelium exceeded all the other temperatures. It can be safely concluded that temperature $30^{\circ} \mathrm{C}$, is the most appropriate temperature required for the yeast's rapid growth and development, as such this temperature was used throughout the yeast culturing. Yeast (Sacchromyces cerevisiae) grows best at temperature ranging from $27^{\circ} \mathrm{C}-35^{\circ} \mathrm{C}$ and this experiment brought that out. Figures 5-7 Treatments $1 \& 2$ were not significantly different from each other but were significantly different from the rest of the treatments. Treatments $4 \& 5$ were not significantly different from each other but were different significantly from the other treatments. Treatment 3 on the other hand was significantly different from all the treatments. There was no significant difference amongst treatments 2, $3 \& 4$ however; these treatments were significantly different from treatments 1 \& 5 (Tables 1-5).

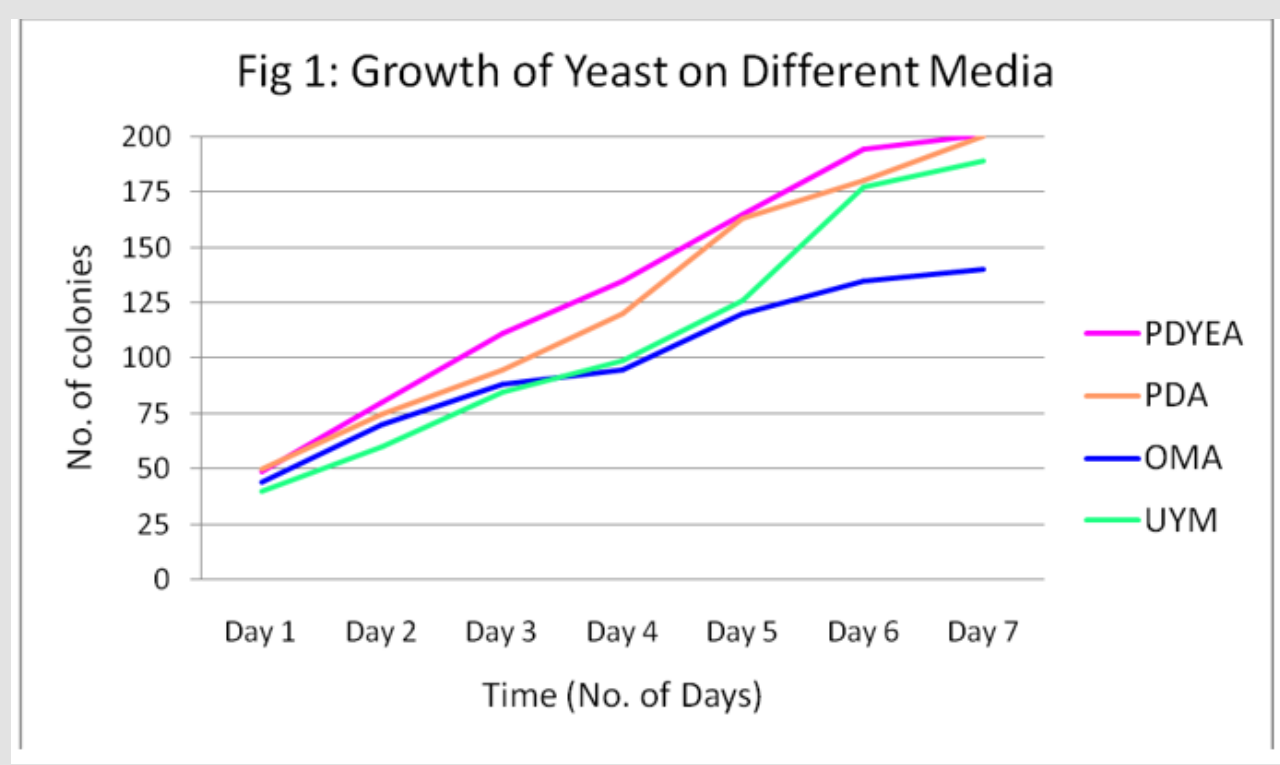

Figure 1: Growth of Yeast on Different media.

PDYEA: Potato Dextrose Yeast Extract Agar

PDA: Potato Dextrose Agar

OMA: Oatmeal Agar

UYM: Universal Yeast Medium 


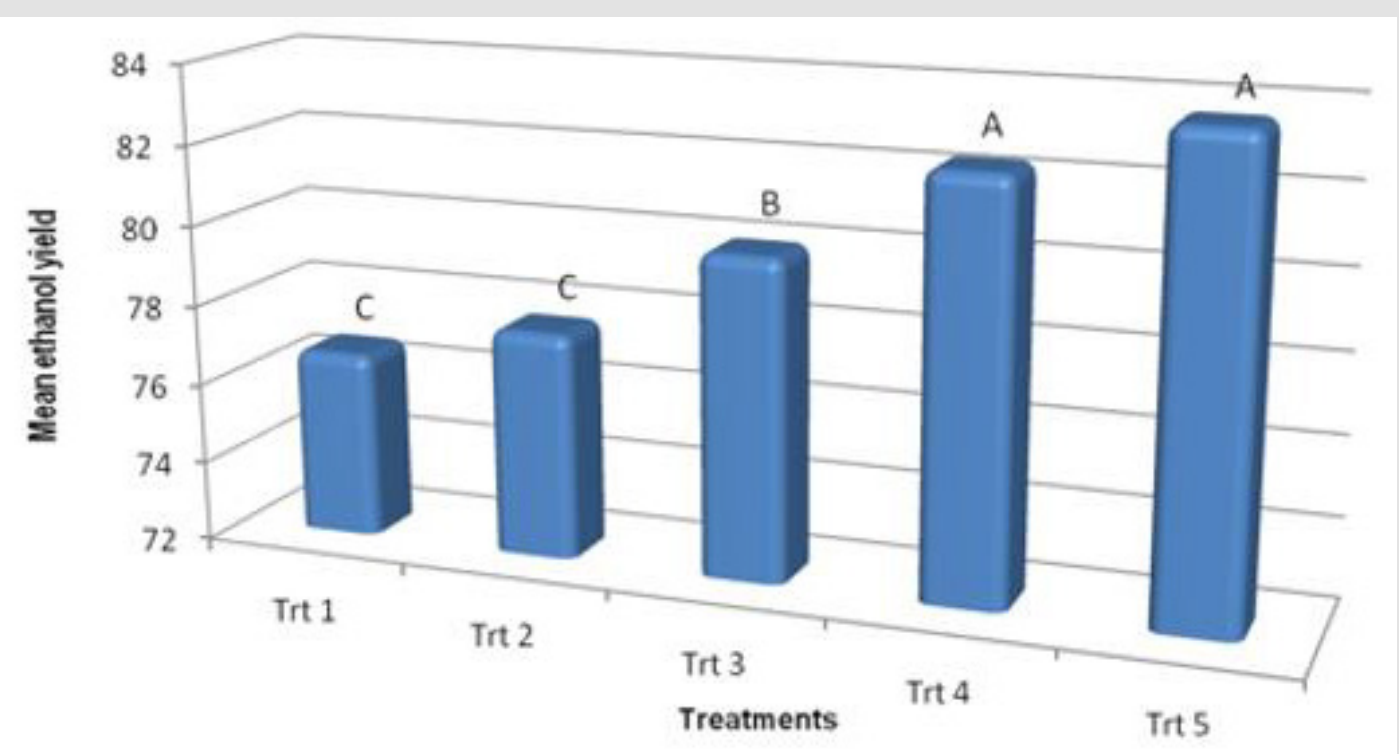

Figure 2: Ethanol Yield from J. leaves (Mean-ml).

Treatments:

Trt $1=1.0 \mathrm{ml}$ Yeast broth

Trt $2=1.5 \mathrm{ml}$ Yeast broth

Trt 3=2.0 ml Yeast broth

Trt 4=2.5 $\mathrm{ml}$ Yeast broth

Trt $5=3.0 \mathrm{ml}$ Yeast broth

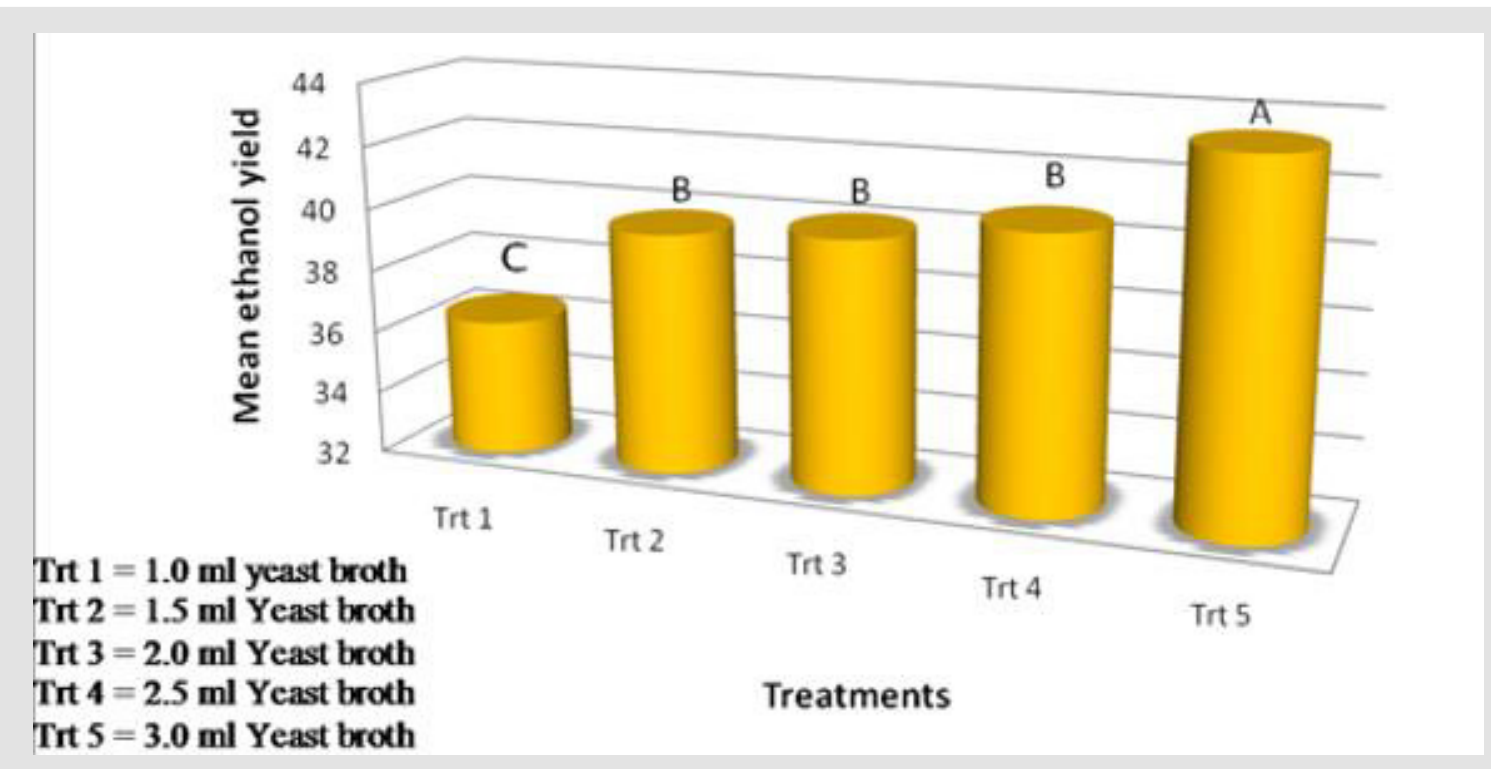

Figure 3: Ethanol Yield from J. seeds (Mean-ml). 


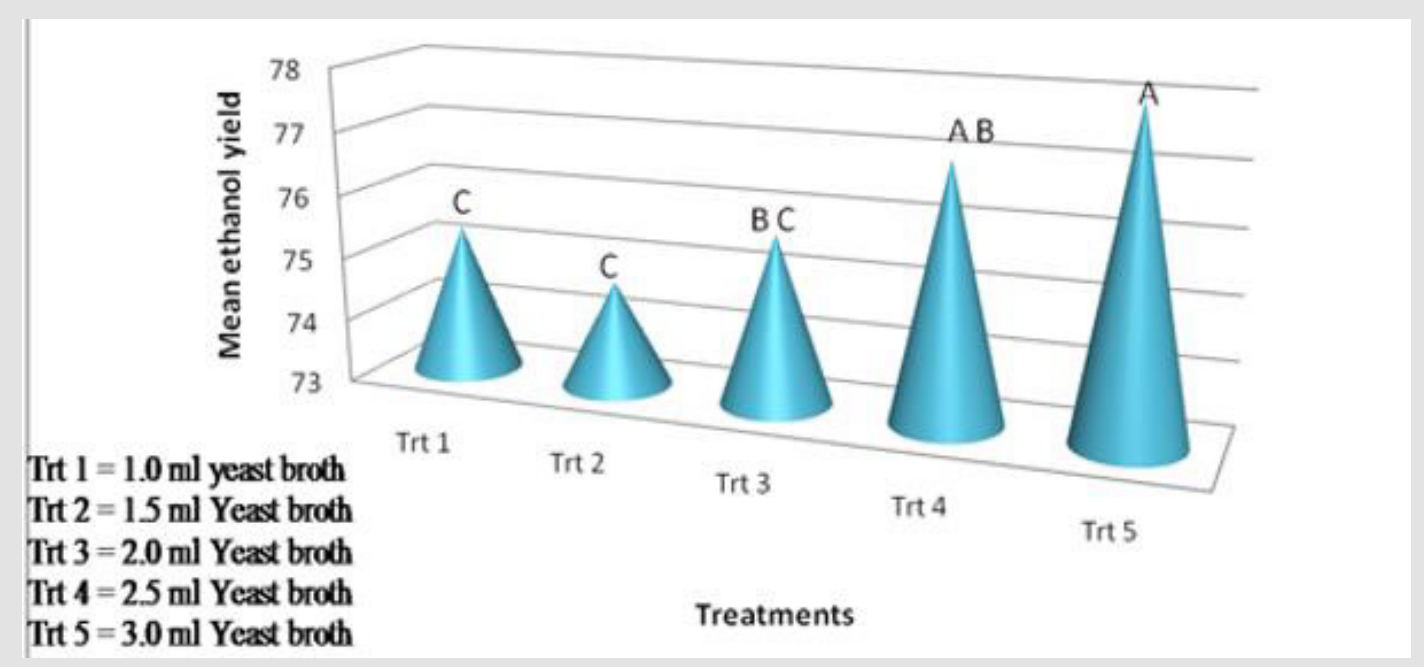

Figure 4: Ethanol Yield from seeds and J. leaves (Mean-ml).

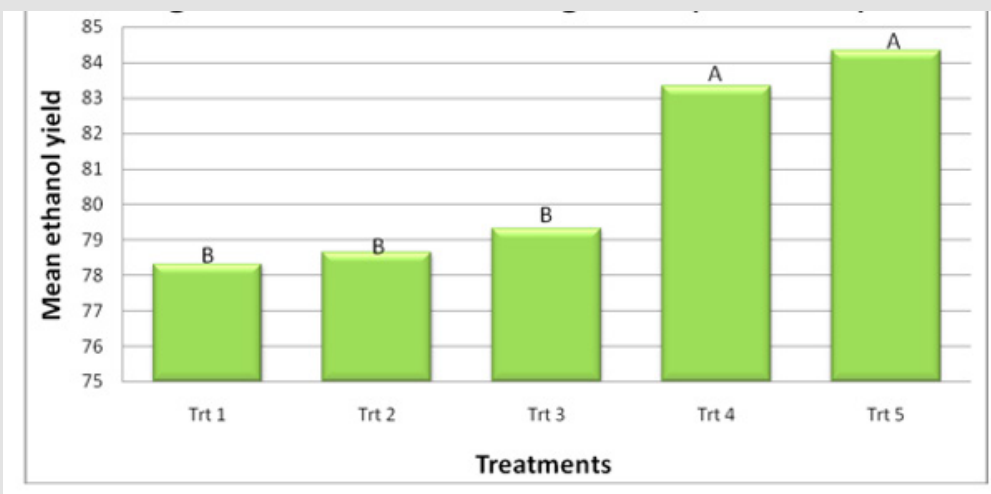

Trt $1=1.0 \mathrm{ml}$ yeast broth

Trt $2=1.5 \mathrm{ml}$ Y east broth

Trt $3=2.0 \mathrm{ml}$ Y east broth

Trt $3=2.0 \mathrm{ml}$ Y east broth
$\mathrm{Trt} 4=2.5 \mathrm{ml}$ Y east broth

Trt $5=3.0 \mathrm{ml}$ Yeast broth

Figure 5: Ethanol Yield from sugarcane (Mean-ml).

Table 1: Effect of $\mathrm{pH}(4,5,6,7,8,9)$ on the growth of Yeast Culture in PDYEA (dry weight in grams).

\begin{tabular}{|c|c|c|c|c|}
\hline \multicolumn{5}{|c|}{ Wet Weight of Yeast Mycelium (Mg) } \\
\hline $\mathbf{p H}$ & Day 1 & Day 3 & Day 5 & Day 7 \\
\hline 4 & 0.8 & 0.9 & 1.1 & 1.3 \\
\hline 5 & 0.9 & 1.1 & 1.3 & 1.5 \\
\hline 6 & 1.1 & 1.4 & 1.6 & 1.9 \\
\hline 7 & 1.3 & 1.6 & 2.0 & 2.5 \\
\hline 8 & 0.8 & 1.0 & 1.1 & 1.3 \\
\hline 9 & 0.9 & 1.4 & 1.5 & 1.6 \\
\hline
\end{tabular}

Table 2: Effect of Temperature (20oC, 25oC, 30oC, 35oC, 40oC) on Yeast growth (wet weight).

\begin{tabular}{|c|c|c|c|c|}
\hline \multicolumn{5}{|c|}{ Temperature oC } \\
\hline 20 & Day1 & Day 3 & Day 5 & Day 7 \\
\hline 25 & 1.2 & 1.3 & 1.6 & 1.9 \\
\hline
\end{tabular}




\begin{tabular}{|l|l|l|l|l|}
\hline 30 & 2.8 & 3.8 & 4.1 & 4.5 \\
\hline 35 & 2.2 & 2.4 & 2.6 & 3.5 \\
\hline 40 & 1.0 & 1.4 & 1.8 & 2.0 \\
\hline
\end{tabular}

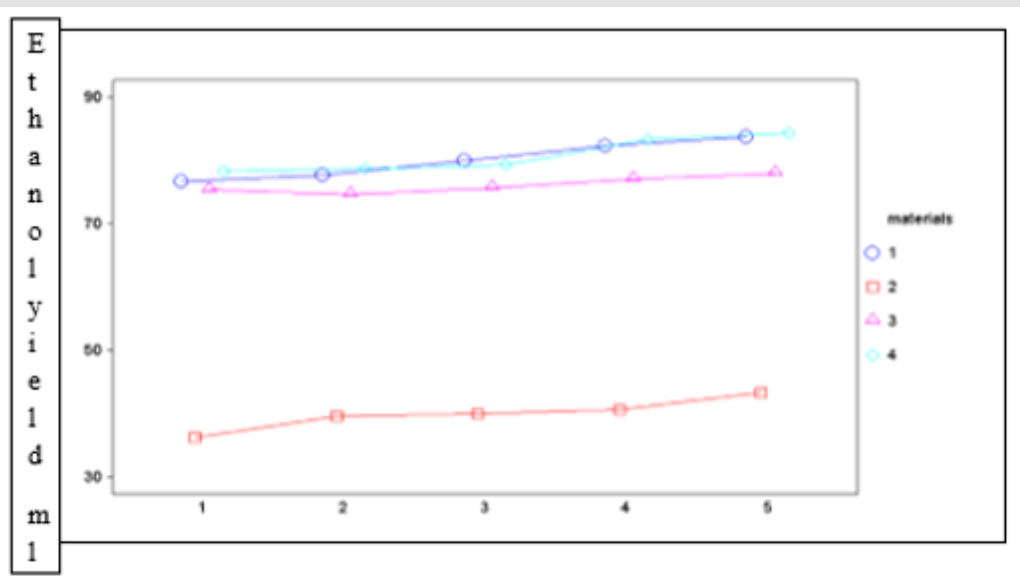

Yeast Broth

\begin{tabular}{|l|}
\hline Treatments: \\
$1=1.0 \mathrm{ml}$ yeast broth \\
$2=1.5 \mathrm{ml}$ yeast broth \\
$3=2.0 \mathrm{ml}$ yeast broth \\
$4=2.5 \mathrm{ml}$ yeast broth \\
$5=3.0 \mathrm{ml}$ yeast broth
\end{tabular}

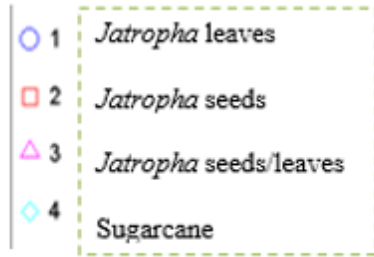

Figure 6: Mean Ethanol Yield for the different materials.

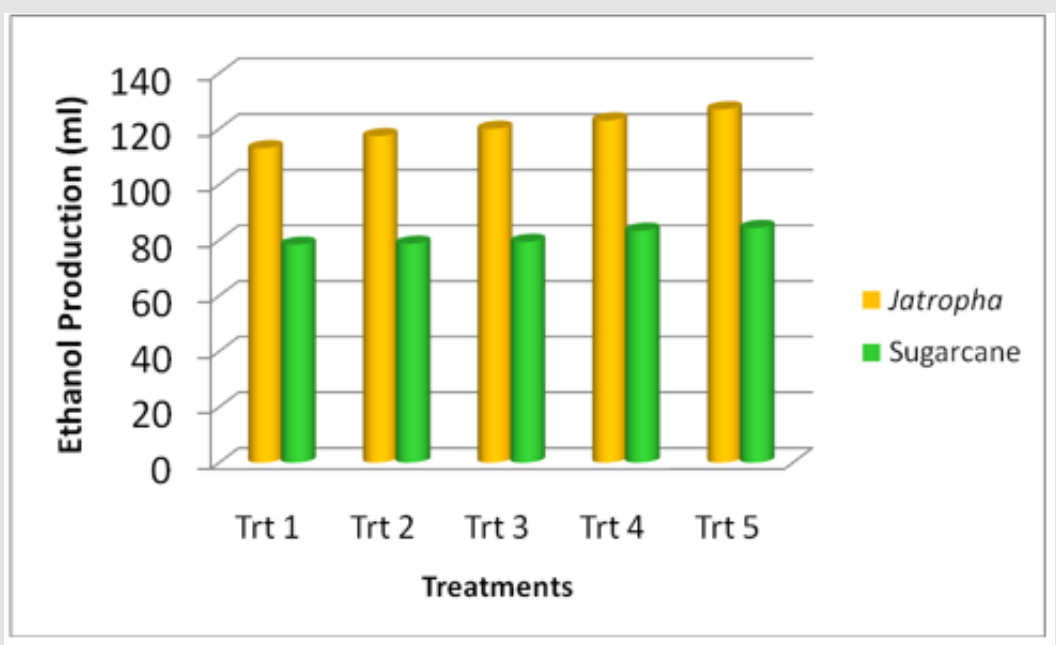

Figure 7: A comparison of Jatropha curcas and Sugarcane ethanol production (ml). 
Table 3: Showing the various substances (Alcohols, Esters) present in the ethanol of Jatropha leaves (g/hl).

\begin{tabular}{|c|c|c|c|c|c|}
\hline $\begin{array}{c}\text { Substances } \\
\text { (alcohols, esters) }\end{array}$ & $\begin{array}{c}\mathrm{T}_{1} \\
(\mathrm{~g} / \mathrm{hl})\end{array}$ & $\begin{array}{c}\mathrm{T}_{2} \\
(\mathrm{~g} / \mathrm{hl})\end{array}$ & $\begin{array}{c}\mathrm{T}_{3} \\
(\mathrm{~g} / \mathrm{hl})\end{array}$ & $\begin{array}{c}\mathrm{T}_{4} \\
(\mathrm{~g} / \mathrm{hl})\end{array}$ & $\begin{array}{c}T_{5} \\
(\mathrm{~g} / \mathrm{hl})\end{array}$ \\
\hline Acetaldehyde & - & - & - & - & - \\
\hline Methanol & $1.63 \mathrm{E}+04$ & $1.98 \mathrm{E}+04$ & $2.22 \mathrm{E}+04$ & $2.71 \mathrm{E}+04$ & $2.83 \mathrm{E}+04$ \\
\hline Acetone & - & - & - & - & - \\
\hline Methylacetate & - & - & - & - & - \\
\hline Propanol & 10.3698 & 18.82319 & 29.78272 & 13.40824 & 15.85594 \\
\hline Ethylacetate & 199.2541 & 236.12835 & 277.58354 & 323.17265 & 446.39246 \\
\hline Butan-2-ol & - & - & - & - & - \\
\hline Isobutanol & 19.4153 & 25.37075 & 31.12644 & 17.83004 & 22.98671 \\
\hline Butan-1-ol & - & 1.97285 & - & 1.69495 & 1.07825 \\
\hline Acetal & - & - & - & - & 6.54731 \\
\hline Iso amyl alcohol & 456.54556 & 531.53909 & 765.00714 & 739.35666 & 1010.08442 \\
\hline Active amyl alcohol & 12.46505 & 17.65911 & 41.44734 & 18.14454 & 21.633 \\
\hline Pentanol & 0.25465 & 1.80657 & 4.90151 & $7.22 \mathrm{E}-01$ & 1.36585 \\
\hline Furfuraldehyde & 5.04989 & 7.57291 & 8.05843 & 5.12805 & 6.0035 \\
\hline Totals: & $1.70 \mathrm{E}+04$ & $2.31 \mathrm{E}+04$ & $2.10 \mathrm{E}+04$ & $2.82 \mathrm{E}+04$ & $2.98 \mathrm{E}+04$ \\
\hline
\end{tabular}

Note: $\mathrm{e} 4=1 \times 10000$

i.e. $=1.6317 \mathrm{e} 4=1.6317 \times 10000=16317$

Table 4: Showing the various substances (Alcohols, Esters) present in the ethanol of Jatropha seeds (g/hl).

\begin{tabular}{|c|c|c|c|c|c|}
\hline $\begin{array}{c}\text { Substances } \\
\text { (Alcohols, Esters) }\end{array}$ & $\begin{array}{c}\mathbf{T}_{\mathbf{1}} \\
\text { (G/H) }\end{array}$ & $\begin{array}{c}\mathbf{T}_{2} \\
\text { (G/HI) }\end{array}$ & $\begin{array}{c}\mathbf{T}_{3} \\
\text { (G/HI) }\end{array}$ & $\begin{array}{c}\mathbf{T}_{4} \\
\text { (G/H) }\end{array}$ & $\begin{array}{c}\mathbf{T}_{5} \\
\text { (G/HI) }\end{array}$ \\
\hline Acetaldehyde & 9.98471 & 12.3456 & 12.56713 & 17.87332 & 18.68223 \\
\hline Methanol & 2675.1523 & 3467.84571 & 3867.20012 & 5995.04305 & 6146.05505 \\
\hline Acetone & - & - & - & - & - \\
\hline Methylacetate & - & - & 61.43201 & 78.22203 & 81.66055 \\
\hline Propanol & 39.57456 & 46.66341 & 63.45436 & 78.46753 & 82.80382 \\
\hline Ethylacetate & 40.65374 & 55.68376 & - & - & - \\
\hline Butan-2-ol & - & - & 78.16547 & 80.75987 & 82.89948 \\
\hline Isobutanol & 50.46748 & 69.53871 & 4.59694 & 3.67893 & 4.73569 \\
\hline Butan-1-ol & 1.85697 & 1.57402 & 9.47583 & 7.95345 & 7.95741 \\
\hline Acetal & 2.87585 & 6.57581 & 566.46389 & 567.86912 & 672.29826 \\
\hline Iso amyl alcohol & 360.58457 & 598.73832 & 89.58473 & 90.47312 & 90.48517 \\
\hline Active amyl alcohol & 50.03832 & 89.45783 & 47.85743 & 50.35487 & 51.45891 \\
\hline Pentanol & 24.56387 & 46.76486 & 9.85761 & 11.00312 & 15.0977 \\
\hline Furfuraldehyde & 6.87034 & 7.95843 & 4810.65552 & 6981.69841 & 7554.13427 \\
\hline Totals: & 3262.62271 & 4403.14646 & & - & \\
\hline
\end{tabular}

Table 5: Showing the various substances (Alcohols, Esters) present in the ethanol of Sugarcane variety DB 7869 (g/hl).

\begin{tabular}{|c|c|c|c|c|}
\hline $\begin{array}{c}\text { Substances } \\
\text { (Alcohols, Esters) }\end{array}$ & $\begin{array}{c}\mathbf{T}_{\mathbf{1}} \\
(\mathbf{G} / \mathbf{H})\end{array}$ & $\begin{array}{c}\left.\mathbf{T}_{2}\right) \\
\text { (G/HI) }\end{array}$ & $\begin{array}{c}\mathbf{T}_{3} \\
\text { (G/H) }\end{array}$ & $\begin{array}{c}\mathbf{T}_{5} \\
\text { (G/HI) }\end{array}$ \\
\hline Acetaldehyde & 1.4587 & 2.74001 & 3.56823 & 5.37741 \\
\hline Methanol & - & - & - & - \\
\hline Methylacetate & - & - & - & - \\
\hline Propanol & 30.44629 & 34.65493 & 35.54857 & 39.47589 \\
\hline Ethylacetate & 20.12213 & 28.028 & 29.42365 & 30.45453 \\
\hline
\end{tabular}




\begin{tabular}{|c|c|c|c|c|c|}
\hline Butan-2-ol & - & - & - & - & - \\
\hline Isobutanol & 143.45723 & 158.10504 & 158.32801 & 154.58228 & 159.27625 \\
\hline Butan-1-ol & - & - & - & - & - \\
\hline Acetal & - & - & - & - & - \\
\hline Iso amyl alcohol & 139.46572 & 154.59895 & 155.73901 & 155.65337 & 156.56324 \\
\hline Active amyl alcohol & - & - & - & - & - \\
\hline Furfuraldehyde & 15.45872 & 21.01734 & 22.78651 & 23.34325 & 23.43211 \\
\hline Totals: & 350.40879 & 399.14427 & 405.39398 & 410.12195 & 417.86397 \\
\hline
\end{tabular}

Treatment 5 was significantly different from all the other treatments as so was treatment 1 . There was no significant difference amongst treatments $1,2 \& 3$. Treatments $3 \& 4$ were not significantly different and so were treatments $4 \& 5$. Treatments $1,2 \& 3$ were not significantly different from each other but were different significantly from treatments $4 \& 5$. On the other hand, treatments $4 \& 5$ were not significantly different. There was no significant difference between the materials, Jatropha leaves and Sugarcane variety DB 7869, however when compared to Jatropha seeds, which gave the lowest overall production of ethanol, was significantly different from the other materials used. Jatropha leaves/seeds was also significantly different from all other treatments as well. There was a steady increase in ethanol yield from the various materials used as the level of yeast broth increases. Sugarcane variety DB 7869 gave the highest value for total alcohol [Alc (vol\%)] for all the treatments used followed by Jatropha leaves, however Jatropha seeds tested the lowest in terms of alcohol strength. This material, Jatropha leaves, has numerous substances (alcohols and esters) and in the largest quantity in $\mathrm{g} / \mathrm{hl}$ present in all the treatments which is an indication that the ethanol produced from this material is not pure. In Jatropha seeds' samples, many alcohols and esters are also found but in smaller quantities in $\mathrm{g} / \mathrm{hl}$, this as well is an indication that the ethanol produced from this material is not pure. This as well suggests that the ethanol produced from this material is not pure. Sugarcane variety DB 7869 has the least amount of substances (alcohol/esters) and in small quantities. The ethanol produced from this material is purer than all the others because of the lower proportion of alcohols/esters1

\section{Summary}

Jatropha curcas (seeds, leaves) gave the highest yield of ethanol as compared to Sugarcane variety DB 7869. As the level of yeast broth increases the production of ethanol also increases. However, Sugarcane variety DB 7869 is purer than Jatropha curcas in terms of other alcohols/esters present. Nonetheless, Jatropha curcas contains the alcohol "methanol" which is also used as a biofuel.

\section{References}

1. Agaceta, LM, Dumag PU, Batolos JA (1981) Studies on the control of snail vectors of fascioliasis: Molluscicidal activity of some indigenous plants. In: Bureau of Animal Industry, Manila, Philippines, NSDB Technology Journal: Abstracts on Tropical Agriculture 7. 38008; 6(2): 30-34.

2. Badger PC (2007) "Ethanol from Cellulose: A General Review" p.17-21. In: J Janick and A Whipkey (Eds.), Trends in new crops and new uses. ASHS Press, 2002, Alexandria, VA. Retrieved on September 2, 2007.

3. Duke JA, Wain KK (1981) Medicinal plants of the world. Computer index with more than 85,000 entries. 3 vols.

4. List PH, Horhammer L (1969-1979) Hager's handbuch der pharmazeutischen praxis. vols 2-6. Springer-Verlag, Berlin.

5. (1988) I Campbell, J H Duffus (Editors) Yeast: A Practical Approach. XV + 289 S., 49 Abb., 52 Tab. Oxford-Washington 1988. IRL Press (Book Review).

6. Little EL, Jr Woodbury RO, Wadsworth F (1974) Trees of Puerto Rico and the Virgin Islands. Second volume. Agriculture Handbook, US Department of Agriculture. No. 449 xiv + 1024 pp.

7. Muñoz P, Bouza E, Cuenca-Estrella M, Eiros JM, Pérez MJ, et al. (2005) Saccharomyces cerevisiae fungemia: an emerging infectious disease. Clin Infect Dis 40(11): 1625-1634.

8. Nathan RA (1978) Fuel from sugar crop. DOE critical review, 1978.

9. Ochse JJ (1980) Vegetables of the Dutch East Indies. Reprinted 1980. A. Asher \& Co., B.V. Amsterdam.

10. Tewari JP, Shukla IK (1982) Inhibition of infectivity of 2 strains of watermelon mosaic virus by latex of some angiosperms. Geobios. Jodhpur, India, 9(3): 124-126.

11. Watt JM, Breyer-Brandwijk MG (1962) The medicinal and poisonous plants of southern and eastern Africa. 2nd ed. E.\&S. Livingstone, Ltd., Edinburgh and London. 


\section{ISSN: 2574-1241}

DOI: $10.26717 /$ BJSTR.2021.37.006062

Gomathinayagam Subramanian. Biomed J Sci \& Tech Res

(C) (P) This work is licensed under Creative

Submission Link: https://biomedres.us/submit-manuscript.php

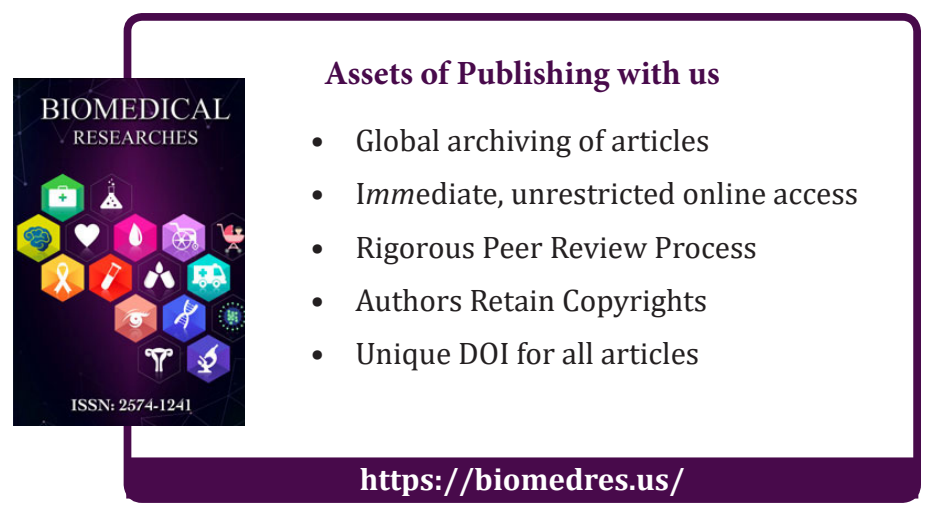

